\title{
Nutrients Analysis of Vermicompost of Water Hyacinth Supplemented with Probiotics
}

\section{T Sakthika ${ }^{1 *}$ and V Sornalaksmi ${ }^{2}$}

${ }^{1}$ Assistant Professor of Zoology, A.P.C.Mahalaxmi College for Women, Thoothukudi, Tamilnadu, India

${ }^{2}$ Assistant Professor of Botany, A.P.C.Mahalaxmi College for Women, Thoothukudi, Tamilnadu, India

*Corresponding Author: T Sakthika, Assistant Professor of Zoology, A.P.C.Mahalaxmi College for Women, Thoothukudi, Tamilnadu, India.

Received: August 20, 2019; Published: September 05, 2019

DOI: 10.31080/ASAG.2019.03.0637

\begin{abstract}
Aquatic weeds are still regarded by many people as a menace because they are not yet aware of the great potential and economic value of these profusely growing uncomfortable plants. This research work presents vermicomposting of aquatic weed water hyacinth (Eichornia crassipes) supplemented with probiotics Lactobacillus sporogens using Eisenia fetida. The nutrients of vermicompost was analysed after 60 days to determine the amount of macro and micronutrients. Aquatic weed supplemented with probiotic bacteria Lactobacillus sporogens showed $18.03 \%$ nitrogen, 32\% phosphorus, $26.86 \%$ potassium, $10.49 \%$ Zinc, $42.88 \%$ copper, $31.22 \%$ Iron, $27.45 \%$ calcium and $43.69 \%$ magnesium than the vermicompost of non supplemented aquatic weed alone. The results of the study showed that enrichment of probiotics with water hyacinth increased the amount of macro and micronutrients in the vermicompost and could be a used as a good biofertilizer in the field to increase the fertility of soil. Moreover, it is an ecofriendly method to solve the chronic problem of Eutrophication in aquatic water habitats.
\end{abstract}

Keywords: Water Hyacinth; Lactobacillus sporogens; Vermicompost; Macro and Micronutrients

\section{Introduction}

Earthworms accelerate organic matter degradation by increasing the available surface area of organic matter through comminution [1]. Given the most favorable conditions of temperature (20$30^{\circ} \mathrm{C}$ ) and moisture (60-70\%), about $5 \mathrm{~kg}$ of worms (numbering approximately 10,000) can vermiprocess 1 ton of waste into vermicompost in just 30 days. Earthworms" body work as a "biofilter", and they have been found to remove the biological oxygen demand (BOD5) by over 90\%, chemical oxygen demand (COD) by $80-90 \%$, total dissolved solids (TDS) by $90-92 \%$ and the total suspended solids (TSS) by 90-95\% from wastewater. Most significant is that there is no sludge formation. Earthworms have been used for land recovery, retrieval and rehabilitation of sub-optimal soils such as poor mineral soils, polder soils, open cast mining sites, closed landfill sites and cutover peat [2].

Vermicomposting simultaneously solves two burdensome problems of modern society. Vermicomposting also saves land and waste transportation costs of Land filling and incineration. It helps to avoid unsightly and hygienic conditions that indiscriminate littering creates. Their small cylindrical bodies behave as bioreactors that aerate soil and breakdown organic waste into nutritious fertilizer. This fertilizer contains various types of plants beneficial substances, such as growth hormones, macro and micronutrients, usable nitrogen, and helpful microorganisms [3].
Water hyacinth (Eichornia crassipes) is a fast growing perennial aquatic plant found in wetlands and which prefers nutrient enriched water [4]. It can cause infestations over large areas of water surfaces and leads to series of problems such as decrease of biodiversity, blockage of rivers and drainage systems, depletion of dissolved oxygen, alterations in water chemistry, environmental pollution, decreased fish population, restricting access to fishing sites and loss of fishing equipment. All of which result in reduction in catch and subsequent loss of lively hoods [5].

Probiotics are one example of microbial-based inoculants which may contain a single-species inoculant or complex cultures where numerous microbial species are grown together [6]. Probiotics are defined as "a live microbial feed supplement which beneficially affects the host animal by improving its intestinal microbial balance" [7]. Use of complex cultures has received more attention because they contain not only those microorganisms, which improve soil fertility but also species of beneficial microorganisms, which can suppress soil borne pathogens [8]

Bacteria in the earthworm gut destroy harmful chemicals ingested by worms and also break down organic wastes. Nitrogen fixation and Nitrogenase activity in casts is higher thus contributing to higher nitrogen fixation in casts than surrounding soil [9]. Considering the importance of bacteria and earthworm in the process of making vermicompost, this research was aimed to analyse 
the nutrients of vermicompost of water hyacinth supplemented with probiotic bacteria Lactobacillus sporogens.

\section{Materials and Methods}

Earthworms and substrates

Earthworms, Eiseniafetida were obtained from a culture bank maintained in the vermicompost unit of Dharangathara Chemical Works Ltd, Sahupuram, Thoothukudi, India. Water hyacinth was taken from Thamirabarani river, near Eral and Cow dung was obtained from a local farmyard near A.P.C.Mahalaxmi College for Women, Thoothukudi. Sporlac sachet was purchased from medical shop and added with water hyacinth in the ratio of $1 \mathrm{~g} / 1 \mathrm{~kg}$ for the experiment.

\section{Experimental design}

The Water hyacinth was dried in air, cut into small pieces and mixed with fresh cow dung (nutrient mixture) in a ratio of 5:1 for the experiment. This mixture was pre decomposed for 15 days to make it palatable for the earthworms.

Vermicompost was prepared in wooden box of 3 feet breadth and 2 feet height. A thin layer of $1.5 \mathrm{~cm}$ thick sterilized soil is filled at the bottom and broken bricks of $5 \mathrm{~cm}$ size were spread over the bottom layer as the supporting material for vermicomposting. Partially decomposed cow dung was placed over the soil layer. The experiment was setup by taking $2 \mathrm{~kg}$ nutrient mixture (on dry weight basis) in each wooden box and no extra feeds were provided during the study. Twenty five earthworms, Eisenia foetida were released over the mixture. The compost of mixture was covered with paddy straw. For control (C), water hyacinth residues were chopped into $1 \mathrm{~cm}$ size pieces left to undergo natural decomposition without the addition of earthworms. Two vermibeds were prepared for vermicompost of water hyacinth by earthworm (E1) and vermicompost of water hyacinth by earthworm supplemented with L. sporogens (E2).Three replicates were setup for statistical analysis of the results.

Vermicomposting was conducted in the Vermicompost Unit of A.P.C.Mahalaxmi College for women, Thoothukudi, in darkness at an average $\mathrm{T}^{\circ} \mathrm{C}$ at $25^{\circ} \mathrm{C}$ and a substrate moisture content of 70 $-75 \%$. The experiment was conducted for 60 days after releasing the earthworms. The experimental set up was kept under shadow and covered with jute sheet. The physical parameters such as $\mathrm{pH}$, temperature and moisture content were monitored with utmost care. The nutrient content of the vermicompost was analysed after 60 days.

Micro Kjeldhal method was used for measuring nitrogen. Available phosphorus was determined by using the spectrophotometer following the stannous chloride method. Potassium was determined by acid digestion method using flame photometer with standard solution [10]. For analysis of $\mathrm{Ca}, \mathrm{Mg}, \mathrm{Cu}, \mathrm{Zn}$ and Fe samples were digested in microwave digester and then analysed by Atomic Absorption Spectrophotometer. All the samples were analysed in triplicates and the mean results were recorded.

\section{Results and Discussion}

At the end of experimental period the nutrient content of vermicompost was analysed to determine the amount of macro and micronutrients in the three vermicomposts composted by Eisenia fetida. The amount of nutrients is presented in table 1 . The increasing percentage of nutrients in the experimental vermicompost is compared to the control and is shown in figure 1.

\begin{tabular}{|l|c|c|c|c|c|c|c|c|c|}
\hline \multirow{2}{*}{ S. No } & \multirow{2}{*}{ Sample } & \multicolumn{3}{|c|}{ Macro Nutrients (g/kg of dry mass) } & \multicolumn{5}{|c|}{ Micro Nutrients(mg/kg of dry mass) } \\
\cline { 3 - 10 } & & $\mathbf{N}$ & $\mathbf{P}$ & $\mathbf{K}$ & $\mathbf{Z n}$ & $\mathbf{C u}$ & $\mathbf{F e}$ & $\mathbf{C a}$ & Mg \\
\hline 1 & (C) & $5.92 \pm 0.86$ & $4.68 \pm 0.44$ & $3.35 \pm 0.78$ & $286 \pm 47$ & $220 \pm 68$ & $922 \pm 120$ & $448 \pm 26$ & $325 \pm 55$ \\
\hline 2 & E1) & $8.68 \pm 1.20$ & $7.24 \pm 0.68$ & $5.40 \pm 0.72$ & $480 \pm 38$ & $315 \pm 92$ & $1460 \pm 284$ & $670 \pm 12$ & $478 \pm 88$ \\
\hline 3 & (E2) & $9.75 \pm 0.93$ & $8.76 \pm 0.83$ & $6.30 \pm 0.56$ & $510 \pm 60$ & $410 \pm 44$ & $1748 \pm 156$ & $790 \pm 62$ & $620 \pm 23$ \\
\hline
\end{tabular}

Table 1: Amount of Macro and Micro nutrients in the control and experimental vermicompost.

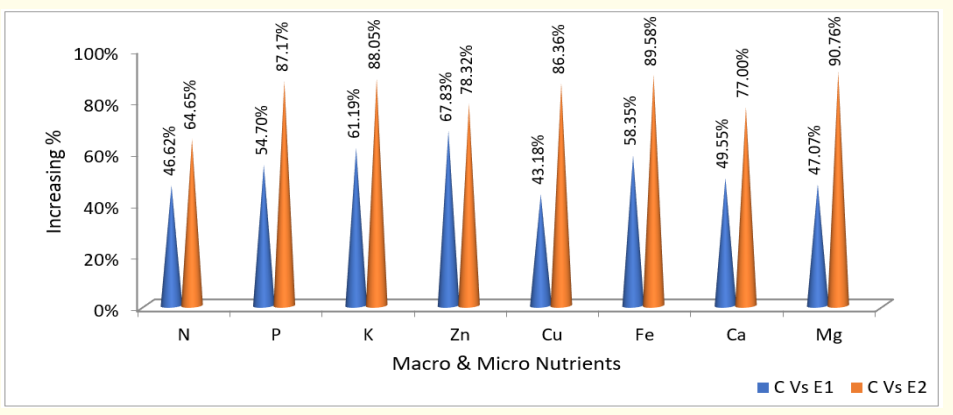

Figure 1: Increasing \% of Macro and Micro nutrients in the control \& experimental vermicompost. 


\section{Macronutrients}

Vermicompost of water hyacinth showed rich in macronutrients NKP (nitrogen $46.62 \%$, potassium $54.70 \%$ and phosphorus 61.19\%) and micronutrients (Zn 67.83\%, Cu 43.18\%, Fe 58.35\%, Ca $49.55 \%$ and $\mathrm{Mg}$ 47.07\%) than the control. Earthworms after ingesting microbes into its gut proliferate the population of microbes to several times in its excreta (vermicast). The microorganisms not only mineralize complex substances (organic waste) into plant available form but also can synthesis whole series of biologically active substances [11]. Earthworms prime the symbiotic gut microflora with secreted mucus and water to increase their degradation of ingested organic matter and the release of assimilable metabolites [11].

During vermicomposting process, the organic matter passes through the worms gut undergoes physical, chemical, and biochemical changes by the combined effect of earthworms and microbial activities. Earthworms not only help the proliferation of microbes by speeding up physical degradation process of organic matter when it passes through the gut but also stimulate other free living aerobic microbial activities in the casts favoring further decomposition [12]. Organic matter that passes through the gut of earthworms released as vermicast results in an increased level of microbial population, microbial activity, microbial respiration, enzyme activity and NPK enrichment, production of polysaccharide gum by bacteria, establishment of lignocellulolytic, nitrifying and nitrogen fixing microorganisms etc. By the action of gut microbes of the earthworm degrade the macronutrients nitrogen, phosphorus and potassium in the aquatic weed water hyacinth. This is the reason of the increased macronutrients and micronutrients of vermicompost of water hyacinth than the natural compost.

\section{Micronutrients}

Vermicompost of water hyacinth supplemented with L. sporogens showed rich in micronutrients (Zn 78.32\%, Cu 86.36\%, Fe $89.58 \%$, Ca $77.00 \%$, Mg 90.76\%) than the control and vermicompost of water hyacinth. Bacteria of the genus Lactobacillus are often characterized by zymogenic microorganisms, i.e., those which are able to ferment carbohydrates in to Lacticacid. Lactobacillus spp. is often found in commercially available microbial inoculants and are reported to have beneficial effects on the growth and yield of crop plants [13]. According to Higa [14] there is a high level of zymogenic activity in freshly plowed soil, much of it due to Lactobacillus spp. It is important to realize that most zymogenic microorganisms produce extracellular enzymes which ferment substrates outside their cells. Consequently, if conditions are favorable, these fermentative enzymes are capable of inducing substrates fermentation long after the organism itself has "died-away" (i.e., no longer detectable).

Most Lactobacillus inoculants contain large populations of Lactic acid bacteria as well as a high level enzymatic activity. Proper soil management practices are vital to maintain a high level of zymogenic activity [15]. The possible reason for the increasing amount of micronutrients in the vermicompost of water hyacinth supplemented by L. sporogens in the present study could be the fermentation of water hyacinth and complete degradation of micronutrients by the zymogenic activity of Lactobacillus sporogens.

\section{Conclusion}

Vermiremediation of hydrocarbon contaminated soil can improve the remediation directly or indirectly due to the several functions of earthworms in the soil. In the bioaugmentation, bacteria belong to the genera Bacillus is widely used. The most commonly used earthworm species for removal and biodegradation of organic contaminants is Eisenia fetida. This study confirms the role of Lactobacillus sporogens in degrading the nutrients of water hyacinth. Several aquatic species, such as Elodea canadensis, Water hyacinth (Eichhornia crassipes), Ceratophyllum demersum etc are used for phytoremediation to remove heavy metals form effluents. The use of plants in conjunction with plant associated bacteria (rhizosphere or endophytic) offers greater potential for bioremediation of organic compounds and in some cases inorganic pollutants than using plants alone in bioremediation. Supplementation of suitable microbes with water hyacinth for bioremediation and safe removal of heavy metal accumulated plants by vermicomposting could be an eco friendly and economically feasible strategy for bioremediation.

\section{Bibliography}

1. Seeber J., et al. "The effect of macro-invertebrates and plant litter of different quality on the release of $\mathrm{N}$ from litter to plant on alpine pastureland". Biology and Fertility of Soils 44.5 (2008): 783-790.

2. Butt KR and CN Lowe. "The development of sustainable earthworm populations at Calvert land fill site". Land Degradation Development 1.5 (2004): 27-36.

3. Silwat., et al. "Estimation of bacterial diversity in soil and vermicompost using sole source carbon utilization (SSCU) profile". African Journal of Microbiology Research 4.4 (2010):255266.

4. Wilson., et al. "Determinants and patterns of population growth in water hyacinth". Aquatic Botany 81.1 (2005): 51-67.

5. Malik. "Environmental challenge vis a vis opportunity. The cade of water hyacinth". Environment International 33.1 (2007): 122-138.

6. Gupta V and R Garg. "Probiotics". Indian Journal of Medical Microbiology 27 (2009): 202-209. 
7. Fuller R. "Probiotics in man and animals". Journal of Applied Bacteriology 66.5 (1989): 365-378.

8. Fatunbi $\mathrm{AO}$ and LNcube. "Activities of Effective Microorganism (EM) on the Nutrient Dynamics of Different Organic Materials Applied to Soil". American-Eurasian Journal of Agronomy 2.1 (2009): 26-35.

9. Ranch T. Earthworm benefits (2006).

10. American Public Health Association (APHA). Standard methods for the examination of water and wastewater 20th edition, Washington (1998).

11. Pramanik P., et al. "Changes in organic - C, N, P and K and enzyme activities in vermicompost of biodegradable organic wastes under liming and microbial inoculants". Bioresource Technology 98.13 (2007): 2485-2494.

12. Kale RD and RV Krishnamoorthy. "Litter preference in earthworm Lampitomaruiti". Proceedings of the Indian Academy of Sciences 90 (1981): 125-128.

13. Higa T and JF Parr. "Beneficial and Effective Microorganisms for a Sustainable Agriculture and Environment". International Nature Farming Research Centre. Atomi, Japan (1994): 16.

14. Higa T. Zymogenic and synthetic soils and crops. University of the Ryukyus, Okinava, Japan (1991).

15. Primavesi A. "ManejoEcologico do Solo". Nobel, Sao Paulo, Brazil (In Potugese) (1990).

Volume 3 Issue 10 October 2019

(C) All rights are reserved by $\mathrm{T}$ Sakthika and

V Sornalaksmi. 